\title{
“AND My SCREen Wouldn't Share...”: efl Student-Teachers' Perceptions of ict in Online Teaching Practice and Online Teaching
}

\author{
“Y NO CONSEguía COMPARTIR LA PANTALla...": LAS PERCEPCIONES DE LOS FUTUROS \\ PROFESORES SOBRE LAS TIC EN LA PRÁCTICA DOCENTE VIRTUAL Y LA ENSEÑANZA EN LÍNEA \\ “Mais Je ne parvenais pas à partager mon écran...” : Perceptions des enseignants \\ D'ANGLAIS EN FORMATION PAR RAPPORT AUX TIC AU COURS DE LEUR STAGE PÉDAGOGIQUE \\ ET L'ENSEIGNEMENT EN LIGNE
}

\section{Nicola Fořtová}

Lecturer, Masaryk University, Brno,

Czech Republic.

fortova@phil.muni.cz

https://orcid.

org/0000-0003-3423-0923

\section{Jitka Sedláčková}

Assistant Professor, Masaryk University, Brno, Czech Republic. jitkasedlackova@mail.muni.cz https://orcid.

org/0000-0002-6636-1541

\section{František Tưma}

Associate Professor, Masaryk

University, Brno, Czech Republic. tuma@phil.muni.cz

https://orcid.

org/0000-0001-9391-1353

\begin{abstract}
The sudden switch to online teaching enforced by the Covid-19 pandemic has impacted teacher education at universities, particularly micro-teachings and teaching practice, as technology has become an inherent part of these processes. The growing body of literature on online teaching and teacher education during lockdown conditions mainly addresses challenges in teacher education and educator perceptions. However, very few studies deal with the perceptions of student-teachers. To fill this gap, a group of teacher educators conducted a research study with 63 students enrolled in a master's Degree in Teaching EFL for Secondary Schools offered at Masaryk University, Czechia. To carry it out, qualitative coding procedures were employed on a dataset of 120 lesson reflections written by students completing their teaching practice via online courses which were ordinarily conducted in person. The purpose was to find out how student-teachers perceived technology use when teaching online. The main findings show that, despite constant comparison between the face-to-face and online classrooms and an initial reliance on the success of technology to determine a lesson's success, the majority of student-teachers normalized technology as a platform for teaching, using technology-specific language for teaching strategies and classroom events. These findings suggest that online teaching and learning should be seen as an integral part of teacher education.
\end{abstract}

Keywords: Teacher education; online teaching; teaching practice; EFL; perceptions; ICT; COVID-19.

Received: 2021-02-28 / Accepted: 2021-08-03 / Published: 2021-09-11

https://doi.org/10.17533/udea.ikala.v26n3a03

Special issue on The Role of Technology in Language Teaching and Learning amid the Crisis Generated by the COVID-19 Pandemic. Editors: Marta González-Lloret, University of Hawai'i at Mānoa, uSA; Laia Canals, Universitat Oberta de Catalunya, Spain; Jorge Pineda, Universidad de Antioquia, Colombia.

(C) 2021 Universidad de Antioquia. This is an open access article distributed under the terms of the Creative Commons License BY-NC-SA 4.0 International. 


\section{RESUMEN}

La repentina necesidad de pasar a la docencia en línea impuesta por la pandemia de Covid-19 ha tenido un impacto en la formación de docentes en las universidades, especialmente en lo relacionado con la micro-enseñanza y las prácticas docentes. El creciente corpus de literatura sobre docencia en línea y formación de profesores en condiciones de confinamiento aborda principalmente los retos de la formación de profesores y las percepciones de los educadores, pero pocos estudios se ocupan de las percepciones de los docentes en formación. Para llenar este vacío, un grupo de formadores de docentes realizaron una investigación con 63 estudiantes de la maestría en Enseñanza del Inglés como Lengua Extranjera (ILE) en Instituciones de Educación Secundaria, ofrecido por la Universidad de Masaryk, República Checa. Para llevarla a cabo, codificaron cualitativamente 120 reflexiones de clase escritas por los estudiantes que hacían sus prácticas docentes en línea en cursos diseñados para dictarse en forma presencial. El objetivo era ver cuál era su percepción de la tecnología para la docencia en línea. Los principales hallazgos muestran que, pese a la comparación constante entre las clases presenciales y virtuales y a una confianza inicial en el éxito de la tecnología como determinante del éxito de la clase, la mayoría de los docentes en formación normalizaron el uso de la tecnología como plataforma educativa, usando un lenguaje específico de la tecnología para sus estrategias pedagógicas y las actividades de la clase. Estos resultados indican que la docencia y el aprendizaje en línea deben integrarse a la formación de docentes.

Palabras clave: formación de docentes; enseñanza en línea; práctica docente; percepciones; ILE; TIC; COVID-19.

\section{RÉSUMÉ}

Le soudain changement à l'enseignement en ligne imposé para la pandémie de Covid-19 a eu des impacts considérables sur la formation des enseignants, particulièrement sur le micro-enseignement et le stage pédagogique, compte tenu que la technologie est devenue un composant important de ces processus. Le croissant corpus de littérature sur l'enseignement en ligne et la formation des enseignants dans des mesures de confinement s'occupe surtout des défis dans la formation des enseignant et les perceptions des enseignant, mais peu des études s'occupent des perceptions des enseignants en formation. Pour combler cette lacune, un groupe de formateurs d'enseignants ont mené une recherche avec 63 étudiants du master en éducation de l'université de Masaryk, République tchèque, qui faisaient leurs stages comme enseignants d'anglais langue étrangère au secondaire. Dans ce but, nous avons codifiée qualitativement une série de données dans 120 réflexions de classe écrites par les étudiants à partir de leurs cours donner en ligne quoiqu' ils étaient préparés pour le présentiel. Cela visait à voir les perceptions des enseignants en formation sur la technologie pour l'enseignement en ligne. Les principaux résultats montrent que, malgré la comparaison constante entre les classes présentielles et virtuelles et une confiance initiale dans le succès de la technologie comme déterminant de la réussite du cours, la plupart des enseignants en formation ont normalisé l'utilisation de la technologie, en tant que plate-forme éducative, utilisant un langage spécifique à la technologie pour leurs stratégies pédagogiques et leurs activités de classe. Ces résultats indiquent que l'enseignement et l'apprentissage en ligne devraient être intégrés dans la formation des enseignants.

Mots-clés : formation des enseignants ; enseignement en ligne ; stages pédagogiques; ALE ; TIC ; COVID-19. 


\section{Introduction}

With the Covid-19 pandemic, schools and universities suddenly had to switch the delivery of education to the online environment. This switch has had a significant impact on the ways that teacher education programs are carried out, mainly in their practical components. Information and communication technologies, including tools for synchronous and asynchronous communication, have become an inherent part of the processes in teacher education programs, while face-to-face sessions on campus or within school placement have been cancelled or significantly limited. It follows that it is worthwhile examining the ways in which technology has become intertwined with teacher education under the changing circumstances caused by the pandemic.

Before we embark upon detailing the focus of the study, we should highlight that we understand teaching as a profession in the sense that teachers as members of a professional community (1) possess in-depth specialist knowledge about teaching as well as the ability to define it, (2) need a thorough initial academic and further education, (3) visibly take serious responsibility (characterized by maximum autonomy), and (4) are committed to social welfare/service in terms of meeting a significant need of society (see also Malin, 2017). This view has several implications for the way that we approach the ways students perceive their teaching experience. Firstly, the practical experience of students cannot be reduced to the "training" of classroom procedures, but it should be meaningfully linked to the body of knowledge addressed and developed in other courses within teacher education programs. This includes the concept of pedagogical content knowledge (PCK; Shulman, 1987) which has been extended to technological and pedagogical content knowledge (ТРACK) by incorporating technology knowledge (Mishra \& Koehler, 2006; see also Tseng et al., 2020, Nasri et al., 2020; Gao \& Zhang, 2020; Heath \& Segal, 2021). This seems to be central when the teaching and learning processes are to be realized in online environments, as is the case with the Covid-19 pandemic.

Second, we recognize the wide range of possibilities, considerations, and challenges that English as a foreign language (EFL) teacher education entails (e.g., Johnson, 2016; see also Darling-Hammond \& Bransford, 2005), upon which we now concentrate the theory and research in the reflective practice tradition. In this view, reflection aims to help student-teachers make sense of their practical experiences, such as teaching practice or micro-teaching performances. This reflection-onaction may relate one's practical experience with more general aspects of the knowledge base for teaching, as discussed above. The integration of theoretical and practical aspects is outlined as one of the strategies for high-quality teacher learning and teaching by Darling-Hammond (2017).

In this empirical study, we focus on the practical component and related reflective writing of EFL student-teachers within a teacher education program in Czechia, which was the eighth most affected country in the world (Pettersson et al., 2020) and reported having "the second-highest per capita death rate over seven days in the world" in autumn 2020 (Cameron, 2020, para. 1). During the lockdown, both universities and upper secondary schools had to switch to an online mode of teaching. Building on data from an English language teacher education program, we explore the reflective writing produced by students who did the practical component of their teacher education online. This study seeks to answer the following research question: How do student-teachers perceive technology use when teaching online? Our research contributes to the study of teacher education by reporting on how students perceived their own online teaching and, more specifically, how they themselves adapted to the technological aspects of the online delivery. Building on the literature on reflective practice and on changes caused by the COVID-19 pandemic, we argue that student-teachers have a dynamic relationship with 
technology and teaching online, which is visible through four distinct perceptions of technology use that emerged from the analysis (a comparison of the face-to-face and online teaching environments in favor of the latter, a view that technology can be used to substitute the traditional classroom, a belief that the online environment is not "real" like the face-to-face classroom, an action plan to improve ICT skills and thus become a better teacher). The challenges of teaching online, in the end, do not outweigh the benefits.

\section{Theoretical Framework}

The following chapter presents the approaches to and the significance of reflection in teacher education and development. The existing research on the impact of the COVID-19 pandemic on teacher education is then discussed and related to the presented research.

\section{6}

\section{Reflective Practice in EFL Teacher Education}

Mann and Walsh (2017, pp. 8-9) argue that while the literature on reflective practice generally emphasizes its importance in teacher education and professional practice, there seems to be no commonly agreed definition. They conclude that many authors emphasize the role of experience and the intellectual and affective processes related to it. Schön's $(1983,1987)$ distinction between reflection-in-action, which takes place during the professional experience, and reflection-on-action (i.e., analyzing a past professional experience) represents an important conceptual cornerstone. While professional performance, such as teaching a class, can be guided by automatized routines and tacit knowing, reflection-in-action comes into play especially when something surprising or unwanted occurs during the performance (Schön, 1983). Student-teachers who are engaged in reflection-onaction can become more aware of and responsive to various aspects of the professional activity, which can, in turn, help them engage in reflection-in-action.

In EFL teacher education, reflection-on-action can be implemented in many ways (Farrell, 2019; Mann
\& Walsh, 2017). In this study we concentrate on reflective writing in which student-teachers were asked to return to their experience, attend to their feelings and re-evaluate the experience. This was done to encourage them to observe relationships between old and new ideas and incorporate the resulting knowledge into their normal ways of operating (Boud, 2001, pp. 13-14). This reflective circle roughly corresponds to Gibbs' (2013) structured debriefing, as it provides guidance for student-teachers, who were asked to describe the action, focus on one's feelings and reactions, analyze the situation, draw conclusions and devise an action plan. This way student-teachers can better understand their own performance and re-frame the knowledge that underlies it. Specifically, in the context of an online teaching experience, it also seems unavoidable for one to compare such an experience with his or her own previous face-to-face experience as a teacher or as a learner (Brookfield, 2017, pp. 69-72). To sum up, in writing about their teaching experience, student-teachers can engage with their feelings, knowledge, and previous personal experience to help them better understand the experience and to organize their thoughts and ideas about teaching.

Regarding the student-teachers' practical experience, two types of practice are relevant to our empirical study: micro-teaching and teaching practice. We use the term micro-teaching to mean student-teachers teaching one another as part of a university course (Grossman, 2005), while teaching practice denotes student-teacher's placement in EFL courses where they teach and take (partial) responsibility for foreign language classes. Both of these types of practical experience activities were situated within the reflective practice framework, as described above. However, due to the Covid-19 pandemic, these practical experience activities were done online.

\section{COVID-19 and Education}

There are a number of studies that deal with the impact of the COVID-19 pandemic on teacher 
education in various countries, including Australia (Scull et al., 2020), Canada (Nuland et al., 2020), Chile (Sepulveda-Escobar \& Morrison, 2020), Israel (Donitsa-Schmidt \& Ramot, 2020), Malaysia (Nasri et al., 2020), Portugal (Flores \& Gago, 2020), South Africa(Robinson \& Rusznyak, 2020), the UK (Kidd \& Murray, 2020; Velle et al., 2020), the UsA (Loose \& Ryan, 2020; Metscher et al., 2020; Mollenkopf \& Gaskill, 2020; Moroe et al., 2020; Quezada et al., 2020) and Trinidad and Tobago (Kalloo et al., 2020). It follows from these studies that the transition to the online mode of teaching involved a number of challenges, one of which was the school placement of student-teachers. The present study addresses the research gap in that it gives voice exclusively to the student-teachers and examines their views of the technology in online teaching expressed through continuous reflective practice. As Kid and Murray (2020) affirm, students and educators were forced to assert their "pedagogic agility" in order to address the looming "practicum vacuum" that initial teacher education programs faced. Several studies have reported that there was no possibility for student-teachers to complete the practicum, so the teacher educators devised activities in which student-teachers were asked to do micro-teaching with their peers or families or to prepare instructional videos or presentations (Donitsa-Schmidt \& Ramot, 2020; Kalloo et al., 2020; Moroe et al., 2020). In other teacher education programs, student-teachers did their school placement online (Flores \& Gago, 2020; Sepulveda-Escobar \& Morrison, 2020). Our study contributes to both of these strands and fills a gap in the literature as we report on both micro-teaching performances that were an inherent part of a course in EFL didactics and on teaching practice where student-teachers were teaching real students online.

The above-cited studies were written mostly from the perspective of teacher educators and reported on the challenges that the Covid-19 pandemic posed on teacher education programs. Other studies concentrate more on online teaching and teachers' perceptions thereof, building mostly on interviews and surveys (Coolican et al., 2020; Gao \& Zhang, 2020; Spoel et al., 2020). Teachers involved in these three studies report that the training and experience of working in the online environments was a challenging one, thus pointing to the TPACK model mentioned above (Mishra \& Koehler, 2006; see also Tseng et al., 2020). It follows that some tasks that are normally done in faceto-face classes need to be done in a different way or reframed completely when teaching online. Specifically in teaching English as a foreign language English represents not only the subject matter but also the language of interaction. This results in many challenges in an online mode of delivery, such as the need to establish new classroom routines and to address some technological aspects, or the lack of physical contact and control over learners' activity. Our study adds to this body of research by reporting on the perceptions of EFL student-teachers who were, similarly to teachers in these studies, suddenly required to teach online.

In relation to the COVID-19 pandemic, there are relatively many studies that report on the experiences and perceptions of teacher educators and teachers. In addition, studies of the perceptions of learner's parents have begun to burgeon (e.g., Brom et al., 2020; Elgart, 2021; Mantovani et al., 2021). However, to our knowledge, there have only been two studies that concentrate on the perceptions of online teaching by student-teachers enrolled in teacher education programs. One of them is by Nasri et al. (2020), who report on the coping strategies that were employed by student-teachers in their interactions with lecturers and content. This study was based on a teacher educators' response helpdesk and on student-teachers' reflections on their online remote learning. In another study, Sepulveda-Escobar and Morrison (2020) report on the challenges and opportunities that 27 student-teachers faced while undertaking their teaching placement online. Among others, their findings show student-teachers appreciated going beyond the professional knowledge and skills as developed in traditional teacher education programs but also reported on some problems, including a lack 
of direct interaction with the learners, and a lack of "live" teaching experience that would make it possible for them to put into practice some of the classroom management strategies discussed in other courses. By analyzing student-teachers' post-lesson written reflections, our study fills the gap in the literature on student-teachers' perceptions of their teaching online. More specifically, we concentrate on detailing the student-teachers' perceptions of what the technology brings them during their teacher education journey particularly when they are required to teach online.

\section{Method}

This section provides information on the research procedure. The participants and the circumstances within which the research was conducted are described. The data collection and analysis are then detailed.

\section{8}

\section{Participants}

The qualitative research was conducted with 63 first and second-year students of a Master's degree program in teaching EFL for secondary schools at Masaryk University, Czechia; 34 first and 29 second year students. The students' experience with teaching in general and the online environment in particular, varied greatly. Some had experience with teaching English in the online environment, some had experience with teaching face-to-face, and for some this semester was the first time that they had taught.

Although the year groups and the students' individual experience with (online) teaching (or a lack thereof) provided a rich, heterogeneous data set, what all the participants had in common was having to partake in practical tasks online as part of their degree. The effect that this had in terms of a shift to the online environment for teaching in the context of their degree was new and the same for all the students. In this sense we viewed the two groups as homogeneous and thus included the 63 students in one cohort.

\section{Context}

The data set of reflections were collected from two different courses; a first-year EFL didactics course where students were required to micro-teach their peers and a second-year course where students did their teaching practice teaching full lessons of English to students at A2/B1 level. Both courses were previously taught face-to-face. The students were asked to reflect once they had taught.

First-year students were required to reflect on their experience in several stages in writing (i.e., planning a session in tandem, micro-teaching and observing their partner teaching, and looking back at the experience). Their reflection assignments were produced in pairs and were structured by 5 topics for reflection focused on overall feeling, achievement of objectives, unexpected moments what they would do differently, and what they felt they had learnt.

Second-year students were required to produce post-lesson reflections; the semester also concluded with an overall written reflection. The reflections were structured by 10 topics focused on overall feeling, achievement of objectives, analyzing a particular lesson stage and what they would do differently, and what they felt they had learnt.

Based on Gibbs' (2013) framework introduced above, neither set of topics for reflection for the first and second years asked specifically about the role of technology, nor were they meant to be questionnaires but rather a guide for the students to air their thoughts on the experience. Although the individual assignments differed in length and focus, they all belong to the category of reflectionon-action as described above.

\section{Data Collection}

The data detailed above was collected throughout the autumn semester (2020). At the time of analyzing the data, 120 of the expected 150 assignments had been submitted (see Table 1 for an overview 
Table 1 Overview of the Dataset

\begin{tabular}{lcc}
\hline & $\begin{array}{c}\text { First } \\
\text { Year }\end{array}$ & $\begin{array}{c}\text { Second } \\
\text { Year }\end{array}$ \\
\hline Students & 34 & 29 \\
Assignments focusing on reflection & 2 (per pair) & 3 (individual) \\
Final reflection on teaching practice & 0 & 1 \\
Total reflective documents & 34 & 116 \\
Total reflective documents & 34 & 86 \\
submitted at time of data analysis & & \\
Reflective documents mentioning & 29 & 60 \\
technology & & \\
\hline
\end{tabular}

of the reflections). We thus worked with this number. The reflections were integral parts of the courses and we as teacher educators had access to them, as we were responsible for the courses and student assessment. For the purposes of this study, we copied and anonymized the students' assignments and post-lesson reflections. The following label was employed to anonymize the data from the reflections: $\mathrm{Y}$ followed by a number refers to the year that the student is in. $S$ followed by a number represents the student. A followed by a number refers to which number assignment the quote was taken from.

Table 1 gives an overall view of the number of students and reflections. Excerpts from the reflections are presented in the results section.

\section{Data Analysis}

The data was approached through content analysis using some of the techniques proposed by Strauss and Corbin (1998) within the interpretive procedure of grounded theory with the aim of finding underlying themes and uncovering relationships among them. First, all the students' reflective writings were read to extract any passages which dealt with technology. In the next phase, the researchers worked individually approaching the data inductively with the research question in mind. The resulting open codes were then discussed together with the aim of increasing the "transparency, logic, or clarity" of the codes and emerging categories
(Duff, 2012, p. 107). When reading and discussing the initial codes, it became evident that students' remarks on technology either described its usage, evaluated its use and/or its impact, expressed their feelings connected to technology or related to their future plans regarding its use. This corresponded to the way that the reflective assignments were prompted. We thus tried grouping the relevant codes and categories under four labels in relation to some of the phases of Gibbs' model, namely Description, Feelings, Evaluation, and Action Plan.

Since the focus of the research was on students' perceptions of technology use, the use of the reflection framework was regarded as suitable and helpful in differentiating between the various meanings of the students' remarks. Subsequently, code clustering according to their meaning closeness (Bogdan \& Biklen, 2003, p. 161) within the four groups was done individually at first, and later in the group. Description, for example, grouped codes such as Technological Language, and categories Technological language for traditional procedures and Online teachers' room. Feelings included remarks including expressions like frustration, scared, nervous or happy. To ensure that what was put under each category/code was evidenced and not forced into the category/code, the other two authors always read the examples connected by the first author to each category/code.

Through a mutual comparison of the categories and their properties across the material (i.e., axial coding; Strauss \& Corbin, 1998, p. 137), relationships between the individual elements were sought to discover patterns among the individual categories and the four groups in which these were clustered.

\section{Results}

The process of the content analysis revealed a number of themes that intertwine with the reflective process including description and analysis of the experience and designing a plan for the future. In the following section, the findings are 
introduced using some of the stages of Gibbs' model of reflection (2013), namely Description, Feelings, Evaluation and Action Plan. Altogether 159 codes in the four aforementioned categories were produced; Description garnered 51 codes, Feelings 17, Evaluation 65, and Action Plan 26. We looked for emerging themes and what is presented below is typical of student-teachers' reflective writing within the respective categories. To illustrate the findings, quotes from the participants have been included. The quotes have been coded to ensure anonymity. Please see the Data Collection section, above, for details of the codes.

\section{Description}

In their description of the various teaching situations, the student-teachers commonly used technological language freely without providing any explanations or details. The names of diverse web applications and their individual functions or parts appeared frequently and, as in the following example, were a natural part of the description of the course of action: "Jamboard and shared documents were great for group activities. Students were frequently using the Zoom chat, showing reactions, etc" (Y2S17A4). Sometimes the learners were rather more succinct as can be seen from the following reflection made about the practice stage of a grammar lesson: "Ss were cooperative. In the BR, they talked together about the exercise in English; later in the MR, even when one $S$ didn't know, another $S$ told me the right answer" (Y2S15A3). These show that technological terms such as breakout / main room (BR/MR) became a part of the jargon.

The lesson stages, classroom management and individual activities follow the traditional patterns. The technological elements, however, substituted the traditional forms. For example, instead of writing on the whiteboard, looking at a textbook page, filling in an exercise in the textbook, or putting students in groups, student-teachers talked about uploading links and writing answers in chat. In the following example, a student described a lesson stage focused on listening for specific information: "I shared my screen with a table and students' task was to fill the interactive Google table in during the listening. ... Then, I put them into breakout rooms to check their answers with their partners" (Y2S01A1).

Supporting interaction in the classroom, establishing a connection and good rapport with students, providing a variety of tasks and forms, taking lessons off the coursebook page, etc. are important aspects of a successful language class. Clearly, they remained just as important in the online classroom and the student-teachers commonly looked for the technological means to do this:

I decided to take the practice off the textbook so I created a matching game. I sent the students a link for the game and asked them to match the words to create compound nouns and adjectives. I put them into breakout rooms to work in pairs so they could help each other. (Y2S02A3)

The student-teachers commonly seem to believe that achieving interaction and involvement in the online environment is on the one hand even more important: "As this was an online lesson, I wanted the students to be engaged as much as possible" (Y2S14A1). On the other hand, this was even more difficult than in the face-to-face classroom because of the lack of physical presence in one place or, as one student-teacher put it, "the invisible wall between the teacher and the students" (Y2S16A4). This "wall” or barrier makes foreign language teaching even more difficult, as the class is conducted in a language which is not yet fully mastered by the learners. The absence of the possibility of checking what page the learners are on, whether they are ready for the next task, or what they are actually doing is a challenge for the classroom management of every teacher, student-teachers included, and refers to the technological-pedagogical area of the TPACK framework (Mishra \& Koehler, 2006), which is the integration of pedagogical (giving instructions, monitoring, etc.) and technological aspects. However, some content aspects are also addressed 
in the reflective writing. In the excerpt cited above, the student "created a matching game" for the learners to make "compound nouns and adjectives" (Y2S02A3). Other quotes presented in this section also refer to listening comprehension and grammar. It follows that students in their reflective writing addressed all the three central aspects in the TPACK model: technology, pedagogy, and content knowledge.

\section{Feelings}

Reflection on past actions and situations inevitably involves emotions. The student-teachers express a spectrum of feelings regarding technology and its role in their teaching experiences.

These include a number of negative emotions particularly nervousness, apprehension, and even frustration. The negative emotions dominated the reflections with students commonly acknowledging feeling "scared of teaching online" (Y2S01A4), "nervous [...] because breakout rooms didn't function as I wanted" (Y1S10A2) or not feeling "comfortable with online teaching" (Y1S05A1). These feelings typically marked the preparatory or initial stages of both micro-teaching and teaching practice and seemed to diminish with experience, as one of the student-teachers wrote in their final reflective essay:

Surprisingly, I would say that my third strength is the use of technology. Before we started with [teaching practice] I was so scared of teaching online. I had no experience, I did not feel comfortable using ZOOM, but I got used to it and it turned out that I am able to use technology effectively in the end. (Y2S17A4)

Similarly, other student-teachers reflected that, "despite all the initial fears" (Y1S01A1), the lessons usually ran smoothly without technical problems.

However, the respondents also experienced disappointment when various applications, online documents, and procedures did not work as planned due to either technical difficulties or gaps in their knowledge which caused malfunctioning such as wrong sharing settings, not saving the newest version, and so on. The "background dramas when the technology does not work" (Y2S17A4) sometimes became a growing frustration, especially when the respondents felt like they could not influence the situation:

I feel that technology let me down a lot. In my mind, I started panicking. ... My computer stopped working, the screen sharing wasn't working, and the Padlet activities did not work. I also ran out of time. (Y2S13A1)

Technical problems are common, and some of them (e.g., a failing Internet connection or malfunctioning applications) seem to be beyond the control of regular users. Nonetheless, many issues can be prevented or at least solved very quickly by careful planning. Such planning requires a degree of experience and thoroughness. When reflecting on their teaching experience regarding technology, student-teachers were often aware of the need to plan the technical part of the lesson better, that they "could have prepared another option if it doesn't work" (Y2S13A1), or that they needed to plan "to test the tools we work with and the timing of an online class in the future" (Y1S11A1).

On the other hand, technology was sometimes blamed for the feelings of dissatisfaction after the lesson, even if the problems seemed to lie in other areas such as lack of meticulous planning, timing, and staging of the lesson or classroom management. Student-teachers appeared to default to blaming technical issues or their lack of experience with ICT for unsuccessful aspects of a lesson instead of a deeper reflection of the true causes.

\section{However, I don't feel comfortable with online tea- ching (I'm not used to the environment) and due to this I had a problem with time and it caused me to be- come stressed in the second half of the lesson when I realized what time it was. (Y1S05A1)}

Despite the fact that the negative feelings showed more prominence, student-teachers also expressed positive emotions. These were particularly connected to the moments when activities 
using technology worked as planned, especially if these were applications or functions used by the students for the first time:

Finally, I was really happy to be able to familiarize myself with new online platforms, applications and functions well. In particular, I used Kahoot, Jamboard, shared my screen with the students for their better orientation, used various tools like a pointer or some drawing tools during my presentation, played a video online, used breakout rooms for discussions as well as other tools provided by the Zoom application. (Y2S14A4)

The feelings of accomplishment did not solely arise from the ability to use a particular tool but because including the technological aspect brought "another engaging element" (Y2S03A4). It also helped to make the lesson "more entertaining" (Y1S03A1) for the students than simply following a textbook page and served well for surveying the students' existing knowledge or for sensitive error correction. The students reported that using tools such as Jamboard ${ }^{\circ}$ or Google Documents', and functions such as chat or showing reactions, increased the interaction and learner-centeredness of the class. We thus conclude that the studentteachers were not content with using technology for technology's sake but tried to incorporate it to achieve their teaching objectives, thus integrating the knowledge of technology into their developing pedagogical content knowledge.

\section{Evaluation}

As is often the case, separating the individual stages of reflection, particularly the description of events from feelings and evaluative comments, seems to have been difficult for the student-teachers. Objective re-telling of events usually quickly gives way to the assessment of one's performance, the degree of success in the realization of the lesson plan, students' reactions, and the reasons behind these.

Successful implementation of a technological element or execution of an activity involving a new tool or function served as a measurement of the success of the particular lesson stage. In addition, a lack of technical issues seems to have acted as a measure of the success of the whole lesson. For example, during an introductory activity, a student invited their students to Jamboard ${ }^{\circ}$ and to create sticky notes to brainstorm some ideas. In their reflection they wrote: "I feel that the Jamboard activity was well done, all went smooth. It was the first time I used it but it worked well" (Y2S07A2). This shows that rather than concentrating on whether the stage aims were met, the success of the stage was measured by the successful implementation of technology.

Many of the evaluative comments of the studentteachers were based on the comparison of the online and face-to-face teaching environments. The comparison did not typically favor the online environment. Several student-teachers doubted "whether it was even realistic to have a lively discussion via Zoom" (Y1S13A2). Many stated that it would be beneficial if "the students were given more power" (Y1S07A2) in their learning, but some "did not figure out how to perform the activity in a more engaging manner in the online environment without making it confusing or disorganized." There were several instances where face-to-face teaching was referred to as "regular" (Y2S15A2), "normal" (Y1S11A2), and the "real" classroom (Y2S04A3). This notion of online teaching as an interim form may have led to the idea that it is not necessary "to worry about the $[\ldots]$ countless problems with slow Wi-Fi, Zoom that did not work [...] given the fact that the 'accidents' could be avoided in a regular face-to-face environment” (Y2S17A3).

In some instances, the student-teachers evaluate technology as an obstacle to their performance. In the online environment, they are not capable of managing the class in the same way as in the offline setting. Due to the different dynamic and "very limiting [...] lack of non-verbal communication" (Y2S19A4) student-teachers may overcompensate with "blabbering" (Y2S19A4) or what could be referred to as self-talk (unnecessary talk about different things that were not connected to the subject at hand). While this feature can be seen 
as specific to the language classroom because the teacher's language may act as a source of input, the student-teacher here clearly refers to an extensive amount of teacher talk time, which may, in turn, make the class more teacher-centered and the talk difficult to grasp. As addressed in the Description section above, to make their talk more understandable and to adjust to the lack of physical presence, in their reflective writing, student-teachers searched for ways to overcome these limitations and to substitute the traditional procedures from the face-to-face classroom by any means that the technology had to offer, as the following quote illustrates:

\begin{abstract}
Adaptations are inevitable - there is no whiteboard; the teacher cannot circle around the class, moving between the desks and monitoring pairs of students hunched over their tasks. Nevertheless, the lessons of our internal teaching practice showed us that we were able to adapt pretty successfully. Tools such as Google's Jamboard or ZOOM's Breakout rooms substituted the physical classroom satisfactorily. (Y2S16A4)
\end{abstract}

The student-teachers realize that the organization of a successful online lesson that would meet its objectives required changes in the approach and forms. It follows that good planning and gaining some experience (e.g., for a more realistic estimate of time) pays dividends. Careful planning does not only involve timing but also other aspects of classroom management which are affected by the lack of direct contact or an easy general overview of the classroom activity. A student described how, after the first problematic experience with online teaching, she "created paper cards with students' names so [they] can remember what pairs the students were in and who have not spoken yet" (Y2S03A4). Later the same student-teacher introduced another simple improvement and printed their lesson plan in order to have a "paper version of materials because these are easier to manipulate and you do not have to close Zoom to look at them" (Y2S03A4).

Managing all the technological aspects of the online classroom presents an additional challenge for novice teachers mainly in two aspects. Firstly, the lack of experience with technology brings additional stress and apprehension. And secondly, it further divides their attention. Besides the lesson plan, the procedures, the students and the time, care needs to be given to managing the videoconference and other environments used during the lesson and this further aggrandizes multitasking to "an unsurpassable problem":

\footnotetext{
The internal teaching practice was my first experience with teaching English, in addition, it was my first experience teaching online. As a result, I was focusing on my plan, on the technology etc. and it was hard for me to focus on errors students made. The most frequent were the pronunciation errors, but the sound on ZOOM was not always good so it was hard for me to focus on the pronunciation of individual words. (Y2S01A3)
}

It follows from this quote that due to focusing more on technological and pedagogical aspects, the content aspects (here pronunciation) could not always be concentrated on by the studentteachers. Even though technology brought mixed feelings and represented various challenges, when the student-teachers formulated implications based on their experience and its analysis, there seems to be no controversy. Their plans for the future unequivocally include the need to improve in their technological knowledge (Mishra, \& Koehler, 2006):

\section{As I said, I find my lacking technology skills as my bi- ggest problem at the moment, as it interferes negatively with my development as a language teacher. I am acti- vely seeking opportunities to educate myself in this field and I am planning to continue to do so. (Y2S19A4)}

The lack of student-teachers' experience and knowledge of technology was considered the "greatest weakness" (Y2S19A4) and "incompetence" (Y2S19A2). The technology-related knowledge and skills are assessed as inadequate and are commonly reported to result in the studentteachers' lack of confidence. The improvement which was achieved throughout the semester is positive but insufficient. One student remarked that they are used to "traditional course books, additional copied materials and flashcards" and they 
"still lack the confidence in ICT" (Y2S19A4). Whilst another observed that they still do not have a "sufficient level of confidence in this area," which not only prevents them from delivering lessons in a way that they would like but that their "students are aware of this fact" (Y2S08A4). We find this surprising, as the majority of the studentteachers were in their early twenties and in the Czech context could be expected to be familiar with technology and its application. In addition, the latter observation shows that mastering technology is perceived as a crucial step in teacher development.

Technological knowledge is typically represented in their action plan for their future development not only as the aim but also the means. Many student-teachers see the benefits of the accessibility of online resources such as webinars, activity packs, and videos created by experienced teachers or specialized websites "which offer hundreds of high-quality resources to help teachers in their professional development such as articles, videos, publications and courses" (Y2S08A2).

At the same time, less commonly, the use of social media as a personal learning environment for exchanging information and support within the group of student-teachers was seen as irreplaceable, especially in the pandemic situation when face-to-face interaction is highly limited and the student-teachers are living through their (often first) teaching experience individually:

Moreover, we created a Facebook chat for our group where we were sharing our experiences and tips about resources or tools for online teaching. I found that very beneficial, the girls were very supportive. (Y2S01A3)

\section{Discussion and Conclusions}

The findings from the current study show that, during reflection upon their teaching and micro-teaching experiences, students made mention of technological knowledge in several areas and ways. The student-teachers made mention of technology in relation to its use in teaching the language systems and skills and in classroom management. It was commonly noted that the online environment does not provide a direct substitute for the face-to-face language classroom, and skills gained from teaching face-to-face were not easily transferable to the online environment; classroom management issues in particular, such as checking understanding, giving instructions, and monitoring were mentioned, in addition to the lack of nonverbal communication present online. These can be related to the TPACK (Mishra \& Koehler, 2006) model. While aspects of classroom management related mostly to the pedagogical-technological knowledge, the mentions of teaching language systems and the four skills embrace the knowledge of content.

One of the central findings is that student-teachers commonly mentioned technology and technological jargon when describing various situations that occurred during the lessons and when evaluating technology use and its possible impact on their teaching. The findings also show that the student-teachers often connect the use of technology to emotions, especially when a tool has been navigated successfully or when drawing comparisons between the face-to-face and online environment. Another finding of note is that evaluation (65 codes) and description (51 codes) were the most common categories in the reflections on perceptions of technology use, yet student-teachers typically mentioned technology when considering their professional development. A possible explanation for this may be that students have relatively strong opinions about the impact of the use of technology on teaching, yet at the same time realize its growing role and the need to master the technology itself and how to best employ it in the EFL classroom. However, one unanticipated and interesting finding from the data analysis is the emergence of four distinct perceptions of technology use.

Perception one: The things that are normally done in the face-to-face classroom cannot be done online. The evaluative comments show learners' 
surprising lack of faith in the technology and a presupposition of obstacles that technology presents to hinder successful lesson execution. For example, building rapport and connections with the learners, fostering interaction, monitoring successfully, and the lack of physical presence were mentioned as problematic online. This comparison in favor of the traditional classroom accords with findings in other studies which report similar concerns from both student and educator perspectives (Gao \& Zhang, 2020; Sepulveda-Escobar \& Morrison, 2020). Brookfield's observations offer an explanation to this stage in student-teacher thinking as he posits that personal experience is a lens through which we reflect. Therefore, comparison, in this case, between face-to-face and classroom environments, is inevitable (Brookfield, 2017, pp.69-72), and we naturally default to the familiar.

Of interest is that the common initial comparison that favored the face-to-face environment for teaching was made by student-teachers who had limited or no previous teaching experience. It may therefore be pertinent to consider the role that apprenticeship of observation (Lortie, 1975) plays at this juncture. The apprenticeship of observation refers to the effect that (student) teachers' own experiences at school have on them professionally (i.e., the attitudes and orientations one develops as a learner at school influence their classroom practice). This may explain why the student-teachers with little to no teaching experience did not initially normalize the online environment and instead perceived the face-toface classroom as an environment more conducive to learning.

Perception two: Technology, in fact, works as a satisfactory substitute for face-to-face teaching. Evaluative comments in the reflections show a realization that, often despite initial doubts, the student-teachers were able to adapt practice to the online environment. Student-teachers' enactment of their technological, pedagogical, and content knowledge (TPACK; Mishra \& Koehler, 2006) may have caused this shift in perception.
Heath and Segal (2021) report that initially their student-teachers also "wrestled with moving face-to-face technology integration to an online format" (p. 827). Tseng et al. (2020) observed that most teachers displayed "the dominant use of technology in traditional teacher-centered teaching" (p. 1). Both assertions may ring true for the student-teachers, who, prior to practicum online, had integrated technology to enhance the faceto-face classroom experience as either a teacher or learner and saw technology as a means to engage learners in the learning process rather than as a means to promote learner-centered lessons (Chapelle, 2005).

Although tracking the development of the perceptions of technology use in individual student-teachers in the course of the semester was not the focus of the analysis, it may be safe to say that a shift in views is present in our data. The evaluative and emotional remarks in particular often contain structures like at first/initially and afterwards/ after the experience as seen in some of the examples above. In contrast with Sepulveda-Escobar and Morrison's findings (2020), our data revealed an eventual acceptance of the online environment for teaching as adequate, and a recognition of some of its benefits (e.g., visibility of instructions and feedback, the possibility of lesson recording). As the findings in Gao and Zhang (2020) indicate, this may be due to the acquisition of technological knowledge and skills. Prior to the onset of COVID-19, most of the students had not yet taken a course specializing in using technology in EFL teaching during their studies and had "little knowledge and skills for online teaching" (Gao \& Zhang, 2020, p. 8). As the student-teachers acquired some of this technological knowledge and skills in the course of the semester of online learning and teaching skills, their perceptions of the technology seemed to change favorably.

Perception three: Face-to-face teaching remains "the real thing." Evaluative comments in the reflections show that the online classroom is seen to bring problems and to be an interim measure 
that does not replicate an environment equivalent to the face-to-face classroom. The student-teachers often describe problematic elements in their lessons yet express that in the "real" face-to-face classroom they would not have these problems. These findings chime with those of SepulvedaEscobar and Morrison (2020) and Flores and Gago (2020). When negative or challenging aspects arose, for example, a lack of interaction with learners, the student-teachers argued that the online environment "was not a 'real' learning experience" (Sepulveda-Escobar \& Morrison, 2020, p. 599). The sudden change to online teaching and subsequent lack of preparation and guidance that the pre-service teachers had for this, which affected their "readiness" (Goa \& Zhang, 2020; Downing \& Dyment, 2013), may influence their need to default to the notion that only face-to-face teaching is real. As Downing and Dyment (2013) observe, "it can take time to become accustomed to providing and recognising an environment where both students and teaching staff feel engaged, valued, and intellectually and emotionally rewarded" (p. 102).

The fourth and final perception relates to the perceived need to improve technological knowledge and skills for the future teaching of English as a foreign language (i.e., TPACK; Mishra \& Koehler, 2006). This was commonly mentioned in the reflections as the area in which student-teachers needed to grow. Of interest is that the notion of developing technological knowledge was frequently connected to the perceived quality of an English teacher. This indicates student-teacher awareness of the importance of TPACK and their intention to integrate technology in their teaching. These findings correspond with the results obtained by van der Spoel et al. (2020), which show an "urgency to teach online created teachers' intentions to use more technology in their lessons" and that ICT "should be integrated in teacher training programmes" (p. 633). In a similar vein, Goa and Zhang (2020) observe that "participating teachers realized that online EFL teaching $[. .$.$] is limited by$ teachers' mastery of information technology" (p. 12), implying the need for teacher development in this area and for future research on teacher cognition and TPACK.

The different perceptions showing the relationship to technology outlined above were fluid among the students and may tell of a shift in the relationship that the student-teachers have with technology and the benefits and disadvantages that they see that it offered. To an extent, this possible shift shows a navigated transition from initial "pedagogic discomfort" towards "pedagogic agility" within the online environment (Kidd \& Murray, 2020). The perceptions and perspectives outline what we observed in the reflections. It would be anecdotal to comment on the linearity of the development in this study as the temporal aspect of development was not our primary focus, and the design of the reflective assignments structured student-teachers' responses. However, we believe that this outline shows the eventual win of the benefits of online teaching over the challenges, and that differs to others' findings (e.g., Sepulveda-Escobar \& Morrison, 2020). These findings add to the existing body of work on technology use in teacher education during the time of the COVID-19 pandemic and help to fill the current gap in the literature on student-teacher perceptions.

It is without doubt that with the challenges that COvID-19 has brought, online teaching and learning can no longer be seen as an add on but as an integral part of teacher education (Kalloo et al., 2020). What we can see from the data is that student-teachers' skills and ICT literacy were challenged by a lack of readiness and preparation to teach online (Downing \& Dyment, 2013). Student-teachers express the need to improve their technological knowledge implying their intention to integrate technology in their teaching. In agreement with other authors, we too believe that developing TPACK should have its place at the high table in teacher education programs (van der Spoel et al, 2020; SepulvedaEscobar \& Morrison, 2020; Nasri et al., 2020; Kalloo et al., 2020, Gao \& Zhang, 2020; Heath \& Segal, 2021). 
This could be done in three ways. The first way is by adding online learning components to the existing structure, for example, through blended or hybrid learning. This can enhance ICT literacy through enriched experience and exposure to platforms and tools for learning. The second way is by incorporating ICT courses that develop student-teachers' technological knowledge and integrating this knowledge within the pedagogical content knowledge related to teaching English as a foreign language. The third and final way is by preparing teachers for both face-to-face and online classrooms (Metscher et al., 2020). These should all help the student-teachers to adapt to the new normal of online teaching and learning.

Our analysis showed the use of technologyspecific language for teaching strategies and descriptions of classroom events to be common parlance among student-teachers. This, thanks in part to the sudden shift to online teaching, highlights the need for teacher educators to be familiar with the technology and the language that accompanies it not only to be able to follow the student-teacher discussion and reflective writing, but to also guide and enhance instructional practice.

In terms of further research, it would be fruitful to follow the progress in the "real" school classroom of those who had online practicum in lieu of faceto-face teaching. By doing so we may get a glimpse into the extent that learning to teach online prepares the next generation of EFL professionals for their classroom practice.

\section{References}

Bogdan, R. C., \& Biklen, S. K. (2003). Qualitative research for education: An introduction to theory and methods ( $4^{\text {th }}$ ed.). Allyn and Bacon.

Boud, D. (2001). Using journal writing to enhance reflective practice. New Directions for Adult and Continuing Education, 2001(90), 9-18. https://doi. org/10.1002/ace.16

Brom, C., Lukavský, J., Greger, D., Hannemann, T., Straková, J., \& Švaříček, R. (2020). Mandatory home education during the COVID-19 lockdown in the Czech Republic: A rapid survey of $1^{\text {st }}-9^{\text {th }}$ Graders' Parents. Frontiers in Education, 5. https://doi. org/10.3389/feduc.2020.00103

Brookfield, S. D. (2017). Becoming a critically reflective teacher ( $2^{\text {nd }}$ ed.). Jossey-Bass.

Cameron, R. (2020, October 26 $\left.6^{\text {th }}\right)$. Covid-19: How the Czech Republic's response went wrong. BBC News. https://www.bbc.com/news/ world-europe-54639351

Chapelle, C. (2005). Computer-assisted language learning. In E. Hinkel (Ed.), Handbook of research in second language teaching and learning (pp. 743-755). Lawrence Erlbaum Associates.

Coolican, M., Borras, J. C., \& Strong, M. (2020). Argentina and the COVID-19: Lessons learned from education and technical colleges in Buenos Aires Province. Journal of Education for Teaching, 46(4), 484-496. https:// doi.org/10.1080/02607476.2020.1802204

Darling-Hammond, L. (2017). Teacher education around the world: What can we learn from international practice? European Journal of Teacher Education, 40(3), 291-309. https://doi.org/10.1080/026197 68.2017 .1315399

Darling-Hammond, L., \& Bransford, J. (Eds.). (2005). Preparing teachers for a changing world: What teachers should learn and be able to do. Wiley.

Donitsa-Schmidt, S., \& Ramot, R. (2020). Opportunities and challenges: Teacher education in Israel in the COVID-19 pandemic. Journal of Education for Teaching, 46(4), 586-595. https://doi.org/10.1080/026 07476.2020 .1799708

Downing, J. J., \& Dyment, J. E. (2013). Teacher educators' readiness, preparation, and perceptions of preparing preservice teachers in a fully online environment: An exploratory study. The Teacher Educator, 48(2), 96109. https://doi.org/10.1080/08878730.2012.760023

Duff, P. A. (2012). How to carry out case study research. In A. Mackey \& S. M. Gass (Eds.), Research methods in second language acquisition: A practical guide (pp. 95-116). John Wiley \& Sons.

Elgart, M. A. (2021). Learning upended: How Americans experienced the shift to remote instruction. Phi Delta Kappan, 102(5), 48-51. https://doi. org/10.1177/0031721721992566

Farrell, T. S. C. (2019). Reflective practice in L2 teacher education. In S. Walsh \& S. Mann (Eds.), The Routledge handbook of English language teacher education (pp. 38-51). Routledge. 
Flores, M. A., \& Gago, M. (2020). Teacher education in times of Covid-19 pandemic in Portugal: National, institutional and pedagogical responses. Journal of Education for Teaching, 46(4), 507-516. https:// doi.org/10.1080/02607476.2020.1799709

Gao, L. X., \& Zhang, L. J. (2020). Teacher learning in difficult times: Examining foreign language teachers' cognitions about online teaching to tide over COvid-19. Frontiers in Psychology, 11. https://doi. org/10.3389/fpsyg.2020.549653

Gibbs, G. (2013). Learning by doing. Oxford Centre for Staff and Learning Development. https://thoughtsmostlyaboutlearning.files.wordpress.com/2015/12/ learning-by-doing-graham-gibbs.pdf

Grossman, P. (2005). Research on pedagogical approaches in teacher education. In M. Cochran-Smith \& K. M. Zeichner (Eds.), Studying teacher education. The report of the AERA Panel on Research and Teacher Education (pp. 425-476). Lawrence Erlbaum Associates.

Heath, M. K., \& Segal. P. (2021). The trap of technocentrism: (Re)centering pedagogy for emergency remote teaching. In R. E. Ferdig, E. Baumgartner, R. Hartshorne, R. Kaplan-Rakowski, \& C. Mouza (Eds.), Teaching, technology, and teacher education during the COVID-19 pandemic: Stories from the field. Association for the Advancement of Computing in Education (AACE). https://www.learntechlib. org/p/216903/

Johnson, K. E. (2016). Language teacher education. In G. Hall (Ed.), The Routledge handbook of English language teaching (pp. 121-134). Routledge.

Kalloo, R. C., Mitchell, B., \& Kamalodeen, V. J. (2020). Responding to the COVID-19 pandemic in Trinidad and Tobago: Challenges and opportunities for teacher education. Journal of Education for Teaching, 46(4), 452-462. https://doi.org/10.1080/0260747 6.2020 .1800407

Kidd, W., \& Murray, J. (2020). The covid-19 pandemic and its effects on teacher education in England: How teacher educators moved practicum learning online. European Journal of Teacher Education, 43(4), 542-558. https://doi.org/10.1080/0261976 8.2020 .1820480

Loose, C. C., \& Ryan, M. G. (2020). Cultivating teachers when the school doors are shut: Two teacher-educators reflect on supervision, instruction, change and opportunity during the COVID-19 pandemic. Frontiers in Education, 5. https://doi.org/10.3389/ feduc.2020.582561
Lortie, D. C. (1975). Schoolteacher: A sociological study. The University of Chicago Press.

Malin, N. (2017). Theoretical frameworks used in studying professions. Social Work and Social Sciences Review, 19(1), 7-30.

Mann, S., \& Walsh, S. (2017). Reflective practice in English language teaching: Research-based principles and practices. Routledge. https://www.routledge.com/ Reflective-Practice-in-English-Language-Teaching-Research-Based-Principles/Mann-Walsh/p/ book/9781138839496

Mantovani, S., Bove, C., Ferri, P., Manzoni, P., Bianchi, A. C., \& Picca, M. (2021). Children 'under lockdown': Voices, experiences, and resources during and after the COVID-19 emergency. Insights from a survey with children and families in the Lombardy region of Italy. European Early Childhood Education Research Journal, O(0), 1-16. https://doi.org/10.1080 /1350293X.2021.1872673

Metscher, S. E., Tramantano, J. S., \& Wong, K. M. (2020). Digital instructional practices to promote pedagogical content knowledge during COVID-19. Journal of Education for Teaching, O(0), 1-4. https://doi.org/1 0.1080/02607476.2020.1842135

Mishra, P., \& Koehler, M. J. (2006). Technological pedagogical content knowledge: A framework for teacher knowledge. Teachers College Record, 108(6), 1017-1054. https://doi. org/10.1111/j.1467-9620.2006.00684.x

Mollenkopf, D., \& Gaskill, M. (2020). Creating meaningful learning experiences for pre-service and in-service teachers facing interruptions in field experience placements during the COVID-19 pandemic. In R. E. Ferdig, E. Baumgartner, R. Hartshorne, R. KaplanRakowski, \& C. Mouza (Eds.), Teaching, technology, and teacher education during the COVID-19 pandemic: Stories from the field (pp. 303-308). Association for the Advancement of Computing in Education (AACE). https://www.learntechlib.org/p/216903/

Moroe, L. E., Mendez, L., \& Nutta, J. (2020). Virtually remote: How interrupted internships continued in a virtual classroom. In R. E. Ferdig, E. Baumgartner, R. Hartshorne, R. Kaplan-Rakowski, \& C. Mouza (Eds.), Teaching, technology, and teacher education during the COVID-19 pandemic: Stories from the field (pp.303-308). Association for the Advancement of Computing in Education (AACE). https://www. learntechlib.org/p/216903/

Nasri, N. M., Husnin, H., Mahmud, S. N. D., \& Halim, L. (2020). Mitigating the Covid-19 pandemic: 
A snapshot from Malaysia into the coping strategies for pre-service teachers' education. Journal of Education for Teaching, 46(4), 546-553. https://doi.org/1 $0.1080 / 02607476.2020 .1802582$

Nuland, S. V., Mandzuk, D., Petrick, K. T., \& Cooper, T. (2020). Covid-19 and its effects on teacher education in Ontario: A complex adaptive systems perspective. Journal of Education for Teaching, 46(4), 442-451. https://doi.org/10.1080/026074 76.2020 .1803050

Pettersson, H., Manley, B., \& Hernandez, S. (2020). Tracking coronavirus' global spread [interactive map]. https://edition.cnn.com/interactive/2020/health/ coronavirus-maps-and-cases/

Quezada, R. L., Talbot, C., \& Quezada-Parker, K. B. (2020). From bricks and mortar to remote teaching: A teacher education program's response to COVID-19. Journal of Education for Teaching, 46(4), 472-483. https://doi.org/10.1080/02607476.2020.1801330

Robinson, M., \& Rusznyak, L. (2020). Learning to teach without school-based experience: Conundrums and possibilities in a South African context. Journal of Education for Teaching, 46(4), 517-527. https:// doi.org/10.1080/02607476.2020.1800408

Schön, D. A. (1983). The reflective practitioner: How professionals think in action. Basic Books.

Schön, D. A. (1987). Educating the reflective practitioner: Toward a design for teaching and learning in the professionals. Jossey-Bass.

Scull, J., Phillips, M., Sharma, U., \& Garnier, K. (2020). Innovations in teacher education at the time of COVID-19: An Australian perspective. Journal of Education for Teaching, 46(4), 497-506. https://doi.org/10.1 $080 / 02607476.2020 .1802701$

Sepulveda-Escobar, P., \& Morrison, A. (2020). Online teaching placement during the COVID-19 pandemic in Chile: Challenges and opportunities. European Journal of Teacher Education, 43(4), 587-607. https://doi.org/10.1080/02619768.202 0.1820981

Shulman, L. S. (1987). Knowledge and teaching. Foundations of the New Reform. Harvard Educational Review, 57(1), 1-22.

Spoel, I. van der, Noroozi, O., Schuurink, E., \& Ginkel, S. van. (2020). Teachers' online teaching expectations and experiences during the Covid19-pandemic in the Netherlands. European Journal of Teacher Education, 43(4), 623-638. https://doi.org/10.1080/0 2619768.2020 .1821185

Strauss, A. L., \& Corbin, J. M. (1998). Basics of qualitative research: Techniques and procedures for developing grounded theory (2 $2^{\text {nd }}$ ed.). Sage.

Tseng, J.-J., Chai, C. S., Tan, L., \& Park, M. (2020). A critical review of research on technological pedagogical and content knowledge (ТРАСК) in language teaching. Computer Assisted Language Learning, O(0), 1-24. https://doi.org/10.1080/09588221.2020.1868531

Velle, L. la, Newman, S., Montgomery, C., \& Hyatt, D. (2020). Initial teacher education in England and the Covid-19 pandemic: Challenges and opportunities. Journal of Education for Teaching, 46(4), 596-608. https://doi.org/10.1080/02607476.202 0.1803051

How to cite this article: Fořtová, N., Sedláčková, J., \& Tưma, F. (2021). "And my screen wouldn't share...”: EFL student-teachers' perceptions of ICT in online teaching practice and online teaching. Íkala, Revista de Lenguaje y Cultura, 26(3), 513-529. https://doi.org/10.17533/udea.ikala.v26n3a03 
